Original Article

\title{
Responses of tomato hybrid cultivars to soil application of humic acid under greenhouse conditions
}

\author{
Respostas de cultivares de tomate híbrido à aplicação de ácido húmico no solo em casa \\ de vegetação

\section{M. Alenazi ${ }^{\mathrm{a}^{*}}$ (D) and M. M. Khandaker ${ }^{\mathrm{b}}$ (i)} \\ aKing Saud University, College of Food and Agricultural Sciences, Plant Production Department, Riyadh, Saudi Arabia \\ bUniversiti Sultan Zainal Abidin, Faculty of Bioresources and Food Industry, School of Agriculture Science and Biotechnology, Besut, \\ Terengganu, Malaysia
}

\begin{abstract}
Responses of three tomato (Lycopersicon esculentum Mill.) hybrids viz. 'Luanova', 'Savarona' and 'Tessera' to various doses $\left(0,0.5,1.0,1.5\right.$ and $\left.2.0 \mathrm{~g} \mathrm{~L}^{-1}\right)$ of soil application of humic acid (HA) were evaluated in terms of plant growth, productivity and quality of fruits, under greenhouse conditions, during 2011-12 and 2012-13. In addition to improved quality characteristics, higher values for yield and yield components were recorded for tomato fruits harvested from plants of 'Tessera' cultivar compared to those harvested from other hybrids tested, regardless of growing seasons. Plants from 'Luanova' cultivar were, however, earlier in fruiting with higher number of fruits per plant. Soil application of HA presented positive effects on yield and physicochemical quality of tomato fruits irrespective of the dose of HA and the cultivar investigated, in both seasons. Soil application of HA at higher dose $1.5 \mathrm{~g} \mathrm{~L}^{-1}$ exhibited better results in all the three tomato cultivars tested, in terms of their vegetative and reproductive growth, and significantly improved the physicochemical quality of their fruits. Conclusively, the tomato hybrid 'Tessera' was found suitable for cultivation under greenhouse conditions while soil application of aqueous solution of HA @ $1.5 \mathrm{~g} \mathrm{~L}^{-1}$ substantially resulted in higher production of quality tomato fruits.
\end{abstract}

Keywords: tomato hybrids, humic acid, soil drenching, vegetative growth, productivity, fruits quality.

\begin{abstract}
Resumo
Respostas de três híbridos de tomate (Lycopersicon esculentum Mill.) viz. 'Luanova', 'Savarona' e 'Tessera' para várias doses (0, 0,5, 1,0, 1,5 e 2,0 g L-1) de aplicação de ácido húmico (AH) no solo foram avaliadas em termos de crescimento da planta, produtividade e qualidade de frutas, em casa de vegetação, durante 2011-12 e 2012-13. Além das características de qualidade melhoradas, valores mais elevados para o rendimento e os componentes do rendimento foram registrados para frutos de tomate colhidos de plantas do cultivar 'Tessera' em comparação com aqueles colhidos de outros híbridos testados, independentemente das estações de cultivo. As plantas do cultivar 'Luanova', no entanto, frutificaram mais cedo com maior número de frutos por planta. A aplicação de $\mathrm{AH}$ no solo apresentou efeitos positivos sobre a produtividade e a qualidade físico-química dos frutos de tomate, independentemente da dose de AH e do cultivar investigado, nas duas safras. A aplicação de HA no solo na dose maior de 1,5 g L-1 apresentou melhores resultados nos três cultivares de tomate testados, quanto ao crescimento vegetativo e reprodutivo, e melhorou significativamente a qualidade físico-química dos frutos. Conclusivamente, o híbrido de tomate 'Tessera' foi considerado adequado para cultivo em casa de vegetação, enquanto a aplicação no solo de solução aquosa de HA @ 1,5 g L-1 resultou substancialmente em maior produção de frutos de tomate de qualidade.
\end{abstract}

Palavras-chave: híbridos de tomate, ácido húmico, encharca mento do solo, crescimento vegetativo, produtividade, qualidade dos frutos.

\section{Introduction}

Tomato (Lycopersicon esculantum Mill.) is the second largest fresh produce in the world next to potato. Being rich in lycopene with a good blend of vitamins, essential amino acids, minerals and dietary fibers, tomato fruits offer numerous benefits to human health and is therefore consumed in a diverse range of ways and styles - as a raw material or as a vital ingredient of many dishes, sauces, salads and drinks (Nour et al., 2013; Radzevičius et al., 2013). Global annual production of tomato exceeds 163.5 million tons of fresh fruits harvested from around 4.72 million hectares of land (Richardson, 2012; FAO, 2016). The Kingdom of Saudi Arabia (KSA) produces more than

*e-mail: amekhled@ksu.edu.sa

Received: May 25, 2021 - Accepted: August 31, 2021

This is an Open Access article distributed under the terms of the Creative Commons Attribution License, which permits unrestricted use, distribution, and reproduction in any medium, provided the original work is properly cited. 
half a million tons of fresh tomato fruits annually from about 15200 hectares of land whereas nearly half of the annual production of fresh tomato fruits produced within the kingdom comes from the greenhouses. However, the average yield ( $34.9 \mathrm{t} \mathrm{ha}^{-1}$ ) of tomato crop in the kingdom is far below compared to those many European (Belgium 499.6, Netherlands 483.5, Ireland 470.0, United Kingdom 417.8, Demark 357.1, Norway $350.7 \mathrm{tha}^{-1}$ ), Asian (Malaysia 65.5, South Korea 64.2, Japan 61.8, China 51.5 t ha $^{-1}$ ), North American (USA 83.8, Canada $62.3 \mathrm{t} \mathrm{ha}^{-1}$ ), Oceania (New Zealand 116.0, Australia $72.4 \mathrm{t} \mathrm{ha}^{-1}$ ) and Arab League (Morocco 92.3, Kuwait 90.5, Lebanon 72.7, Bahrain 63.5, Jordon 56.3, Oman 53.3, Syria $53.0 \mathrm{t} \mathrm{ha}^{-1}$ ) countries are producing at their farms/greenhouses (Feleafel and Mirdad, 2014; FAO, 2016). In addition to meager cultural practices, the low yield of tomato crop in KSA is partially attributed to its poor soil structure with substantially low activities of rhizosphere microbiome (Abdel-Mawgoud et al., 2007) under its desert climate (extreme heat during the day, a sudden drop in temperature at night and very low annual rainfall) and soil (course in texture with high salt, gypsum and carbonate content) conditions.

Being a major component of humic substances, HA is a complex mixture of many different kinds of acids that contain carboxyl and phenolate groups. It is produced through biodegradation of dead organic matter in many upland streams, dystrophic lakes and ocean water. Being able to form complexes with metallic ions such as $\mathrm{Ca}^{+2}$, $\mathrm{Mg}^{+2}, \mathrm{Fe}^{+2}$ and $\mathrm{Fe}^{+3}$, it is commonly used as a chelating agent, a soil supplement or as a soil conditioner in production practices (Lotfi et al., 2015) in order to improve the physical structure of soil or to enhance its ion exchange and water holding capacities. HA has been reported to improve seed germination (Dinu et al., 2014), growth of seedlings, uptake of plant nutrients (Motaghi, 2014; Dinu et al., 2015), and fruits growth and development (Khaled and Fawy, 2011; Shehata et al., 2011; Mahmoudi et al., 2013) by enhancing photosynthesis (Liu and Cooper, 2002), increasing activities of rhizosphere microbiome, or by stimulating phytohormones (Kazemi, 2013; Asri and Demirtas, 2015; Lotfi et al., 2015) in many crops. In addition to species and variety of crop plants, the beneficial effects of HA on plant growth and productivity, however, largely depend on the origin of the material, the molecular size and the dose of HA (Lima et al., 2011; Shahmaleki et al., 2014). A judicious combination of HA with chemical fertilizers may, therefore, help to improve the performance of low fertile soils and/or of the crops grown under desert climate (Sajid et al., 2012).

The qualitative and quantitative prospects of tomato crop are affected by a number of genetic, environmental and agronomic factors (Gould, 1983; Tabasi et al., 2013). Failure to select a suitable variety for a specific set of agro-environmental conditions may result in reduced production coupled with inferior quality produce (Snyder, 2001; Hanna, 2009). Whereas, cultivation of cultivars that are well-adapted to marginal environmental conditions ensures higher production of good quality fruits (Direkvandi et al., 2008).

Many novel tomato varieties and hybrid cultivars are presently being investigated for their performance under the agro-environmental conditions deemed to be marginal to their growth and productivity (Agyeman et al., 2014) under KSA conditions. However, their cultural management practices need to be standardized prior to their cultivation on large commercial scales. Present studies were therefore aimed at evaluating the responses of three newly introduced tomato hybrid cultivars to soil applications of various doses of HA under greenhouse conditions.

\section{Materials and Methods}

\subsection{The experimental site}

Present studies were conducted during 2011-12 and 2012-13 growing seasons (each growing season started from March until July), in the vegetable greenhouse of Research \& Agricultural Experimental Station of King Saud University, in Dirab (243 30 5" N; 46 37' 34" E) situated about $35 \mathrm{Km}$ south of Riyadh city in KSA. A recent analysis reveals that the soil ( $\mathrm{pH} 7.9$; EC 2.94 dS m $\mathrm{d}^{-1}$ ) contains 32.6\% of $\mathrm{CaCO}_{3}, 0.2 \%$ of organic matter, $4.71 \mathrm{mg} \mathrm{kg}^{-1}$ of nitrogen, $2.6 \mathrm{mg} \mathrm{kg}^{-1}$ of phosphorus, and $325 \mathrm{mg} \mathrm{kg}^{-1}$ of potassium (Al-Rohily et al., 2013).

\subsection{Tomato cultivars and plant growth environment}

Seeds of three newly introduced commercial tomato hybrid $\left(\mathrm{F}_{1}\right)$ cultivars with indeterminate growth pattern, namely Luanova, Savarona and Tessera, were sourced from Enza Zaden Beheer B. V., Haling 1E, Enkhuizen, Netherland, and were germinated in seedling trays under controlled environment $\left(25 \pm 1{ }^{\circ} \mathrm{C}\right.$ day and $18 \pm 1^{\circ} \mathrm{C}$ night temperatures). Four (4) weeks old tomato seedlings from experimental cultivars, visibly healthy and uniform in shape and size, were transplanted into prepared soil in a fiberglass greenhouse during the first week of October, each year in 2011 and 2012. The greenhouse was maintained at $26 \pm 1{ }^{\circ} \mathrm{C} / 19 \pm 1{ }^{\circ} \mathrm{C}$ day /night temperatures with $75 \pm 2 \%$ $\mathrm{RH}$ during the course of crop growth, each season. Plants were grown upright and trained onto a single stem. They were supported by iron wires fixed to their main stems.

\subsection{Application of humic acid (HA)}

Humic acid (Huma K; humic acid 56\%, fulvic acid 30\%, and potassium 6\%) in black granule form was sourced from Ferzan Liquid Fertilizers Plant, Riyadh, Saudi Arabia. Aqueous solutions of Humic acid @ 0, 0.5, 1.0, 1.5 and $2.0 \mathrm{~g} \mathrm{~L}^{-1}$ were soil applied twice, 4 weeks apart, during each of the growing seasons. The first application of HA was well incorporated into the soil before planting. The second soil drench was applied under the growing plants, about $10 \mathrm{~cm}$ around their main stems (Salman et al., 2005) using a back-held spray pump and a spade. The control treatment consisted of soil applications of water only. Each treatment included 220,60, and $200 \mathrm{~kg} \mathrm{ha}^{-1}$ of $\mathrm{N}$ (ammonium sulfate), P (mono ammonium phosphate), and $\mathrm{K}$ (potassium nitrate), respectively, applied through drip irrigation system. Harvest-ripe fruits were picked and weighted twice week ${ }^{-1}$. Harvesting started in midDecember and continued periodically until mid of March, depending on fruits ripening.

\subsection{Experimental setup}

The experiment was set-up as a Randomized Complete Block Design (RCBD) arranged in a split plot system 
replicated four times. Tomato cultivars were allocated to main plots whereas HA treatments were randomly distributed in sub-plots. The area of each sub-plot was 8 $\mathrm{m}^{2}$ that contained 16 tomato plants. The tomato crop was cultivated in rows $1.0 \mathrm{~m}$ apart (row to row distance) while tomato plants were $0.5 \mathrm{~m}$ apart (plant to plant distance) within a row.

\subsection{Data recorded}

Vegetative growth: At first harvest (i.e., 75 days from the date of transplanting), plant height, shoot fresh weight, and shoot dry weight were measured for three representative plants randomly selected from each treatment. For dry weight, shoot samples were oven-dried (at $70^{\circ} \mathrm{C}$ for 48-72 hrs) until a constant weight was achieved. Total leaf area was also recorded using a Portable Area Meter (LI-COR model: 3000A).

Fruits yield \& yield components: Number of fruits plant ${ }^{-1}$ were recorded at first harvest. Early fruits yield, total yield plant ${ }^{-1}$ and total yield ha $^{-1}$, were recorded for the first five harvests. From each replication, ten fruits were randomly selected, weighed and divided into two equal lots. The first lot ( 5 fruits) in each replication was used to determine average weight, length and diameter of individual fruits while the other lot (5 fruits) was used for fruits quality analysis.

Fruits quality: Each lot ( 5 fruits) assigned for analysis of fruits quality was homogenized in a kitchen blender. To determine dry weight of fruits, $50 \mathrm{~g}$ of homogenate from each replication was oven-dried (at $70{ }^{\circ} \mathrm{C}$ for $72-96$ hrs) until a stable weight is achieved. Total sugar (\%) and vitamin ' $C$ ' content were estimated following AOAC (2005) standard methods. Vitamin ' $C$ ' content were expressed as mg ascorbic acid $100 \mathrm{~g}^{-1}$ fresh weight (FW). Total soluble solids (TSS) content was measured by using a portable digital refractometer (PR-101 model, ATAGO, Japan). To determine titratable acidity (TA) of tomato fruits, $10 \mathrm{~g}$ of fruits flesh was ground in a blender and homogenized with $90 \mathrm{~mL}$ of distilled water. The homogenate was filtered through a cheesecloth and clear samples of aliquot were titrated against $0.1 \mathrm{~N} \mathrm{NaOH}$ to an endpoint of $\mathrm{pH} 8.1$ (Turhan and Seniz, 2009). TA was expressed as percentage of grams of citric acid equivalent per $100 \mathrm{~g}$ fresh weight.

\subsection{Statistical analysis}

Data recorded during present investigation were subjected to analysis of variance using SAS statistical software (version 8.1, SAS Institute, Cary NC, USA) (SAS, 2008). Least significant differences (Fisher's protected LSD) were calculated at $P \leq 0.05$ following significant $F$ tests (Steel and Torrie, 1980).

\section{Results and Discussion}

\subsection{Vegetative growth}

In this experiment, significant differences were observed among the three hybrid varieties of tomato studied, in terms of their vegetative growth traits. In general, 'Tessera' exhibited significantly $(P \leq 0.05)$ higher values for plant height, shoot fresh weight, shoot dry weight, and leaf area compared to both 'Luanova' and 'Savarona' (Figures 1A-D). Regassa et al. (2012) reported similar observations
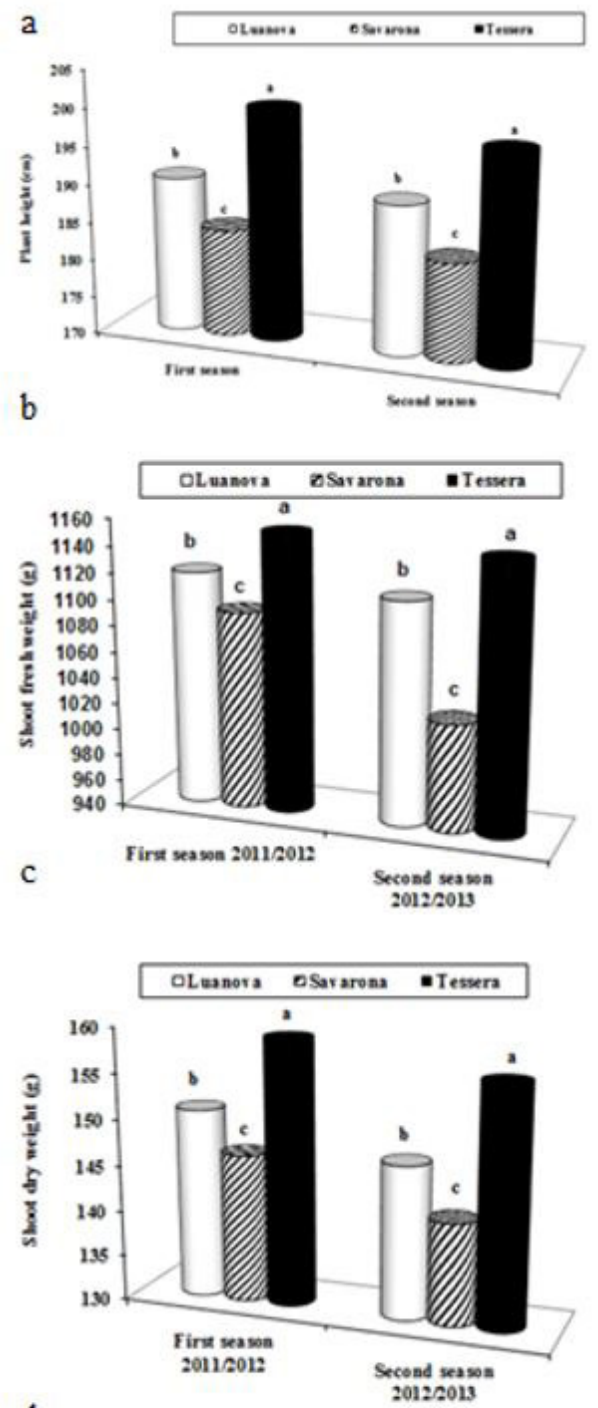

d

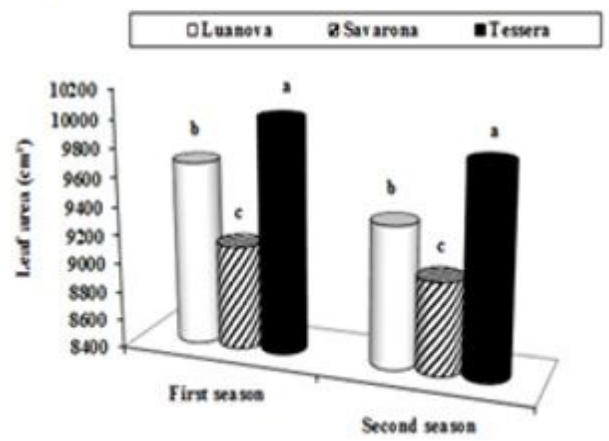

Figure 1. Vegetative growth traits of tomato cultivars: (a) plant height; (b) shoot fresh weight; (c) shoot dry weight; and (d) leaf area during the 2011-2012 and 2012-2013 seasons. 
while evaluating nine tomato genotypes for their yield performance whereas Sajid et al. (2012) suggestively attributed such variations to genetic configuration and adaptability of different cultivars to various greenhouse conditions.

Application of HA significantly enhanced the vegetative growth of tomato plants in this study, irrespective of the cultivars used. Soil dressing of HA @ $1.5 \mathrm{~g} \mathrm{~L}^{-1}$ resulted in significantly $(P \leq 0.05)$ higher values for plant height, fresh weight, dry weight, and leaf area, compared to control and other treatments, irrespective of the cultivars investigated (Figures 2A-D). Kazemi (2013) reported that in 'Rada' cultivar of tomato, application of 20 ppm of HA resulted in higher values for plant height and dry weight compared to those of 5-10 ppm.

Application of HA has generally been suggested to improve the nutrient-uptake efficiency of tomato plants from the soil/environment. Atiyeh et al. (2002) reported that following incorporation of HA into the soil-less container medium, tomato seedlings showed better vegetative growth. They ascribed it to their improved nutrient uptake efficiency. Similarly, Yildirim (2007) and Ebrahim et al. (2012) found that foliar sprays of HA increased vegetative growth of tomato plants as a result of increased nutrient uptake. These nutrients are involved in plant bioactivities and plant growth induction (AbdelMawgoud et al., 2007). In addition, HA plays a vital role in the uptake and transport of nutrients as a result of increased cell permeability (Dursun et al., 2013). Since HA seems to have an ability to interact with various structures of phospholipid in cell membranes thereby serving as carriers of nutrients (Khaled \& Fawy, 2011), it might have a role in transport and availability of both micro- and macro-elements in plants (Kazemi, 2013; Ekinci et al., 2015; Asri and Demirtas, 2015).

\subsection{Fruits yield}

Significant differences were observed among the three hybrid cultivars tested in this study (Figures 3A-D) in terms of the physical characteristics (i.e., number of fruits plant ${ }^{-1}$, average fruits weight, fruits length, and diameter) of their fruits in addition to their yield components (early fruits production, total yield plant ${ }^{-1}$ and total yield ha ${ }^{-1}$ ). 'Tessera' exhibited significantly $(P \leq 0.05)$ higher values for average fruits weight, fruits length and fruits diameter, compared to other hybrid cultivars tested while 'Savarona' and 'Luanova' followed in the order of performance (Figure 3A). Following the similar pattern, the highest values for total yield plant ${ }^{-1}$ and ha ${ }^{-1}$ were recorded for 'Tessera' cultivar. Soil drenching of HA resulted in significantly $(P \leq 0.05)$ higher number of fruits plant ${ }^{-1}$ and produced heavier fruits with higher values for fruits length and diameter, compared to control, irrespective of the growing season and the cultivars (Figures 4A-D). Tomato plants grown in plots supplied with $1.5-2.0 \mathrm{~g} \mathrm{~L}^{-1}$ of HA produced fruits with heavier mean fresh weight (170-172 g), whereas those grown in control produced tomato fruits with the least fresh weight (Figure 4B). Similar results have been reported by Yildirim, 2007. Production of higher number of fruits per plant with heavier fresh weight compared
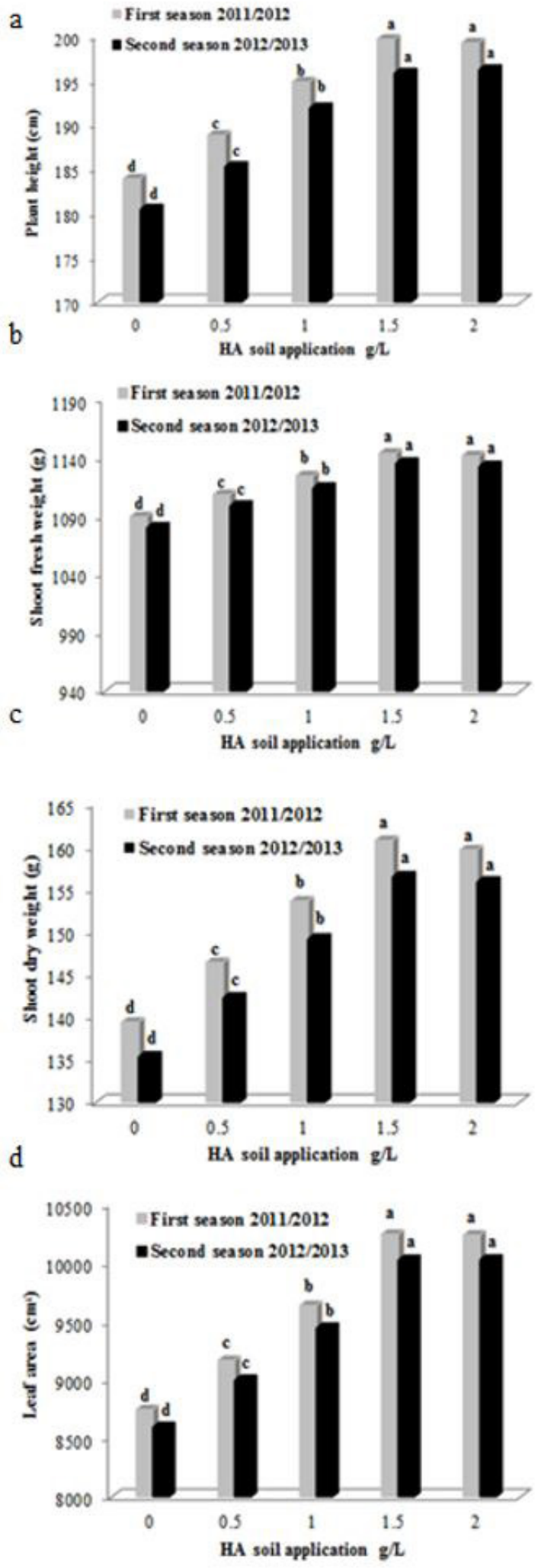

Figure 2. Vegetative growth traits of tomato: (A) plant height; (B) shoot fresh weight; (C) shoot dry weight; and (D) leaf area as affected by the application of humic acid (HA) doses during the 2011-2012 and 2012-2013 seasons. 


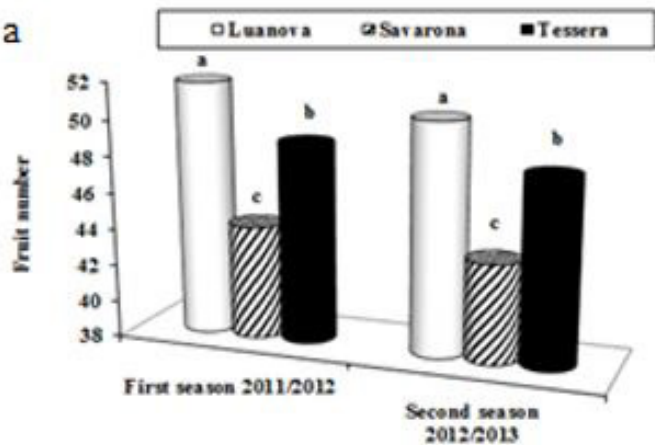

b

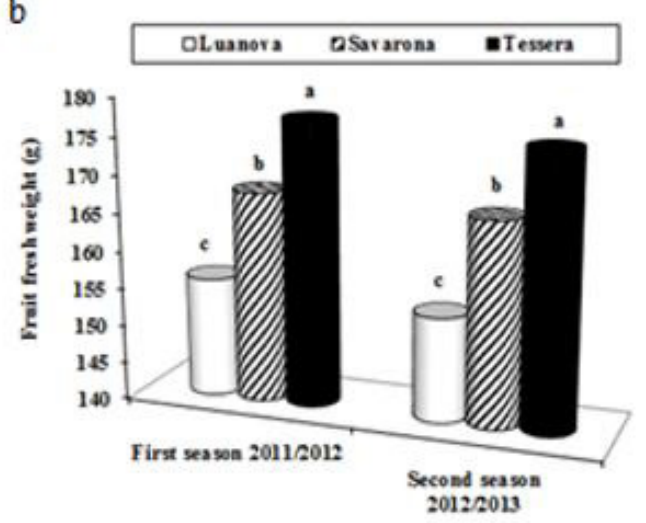

c

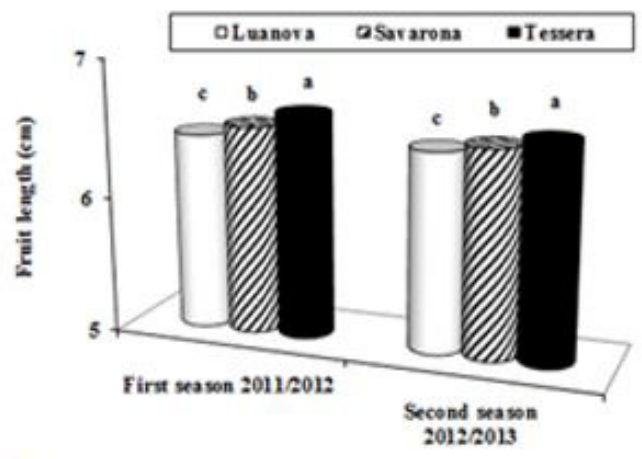

d

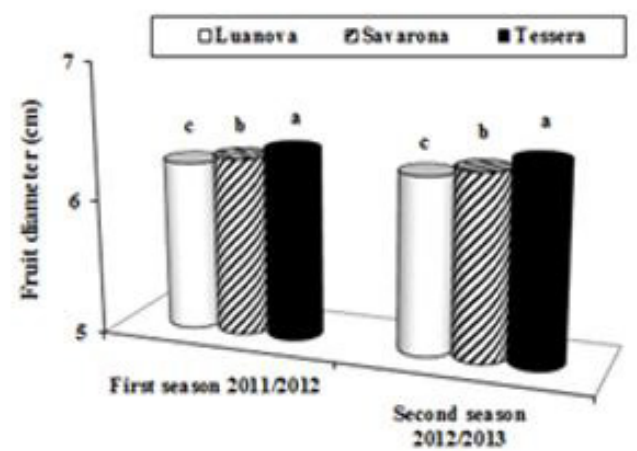

Figure 3. Fruits characteristics of tomato cultivars: (A) fruits number plant-1; (B) fruits fresh weight; (C) fruits length; and (d) diameter during the 2011-2012 and 2012-2013 seasons.

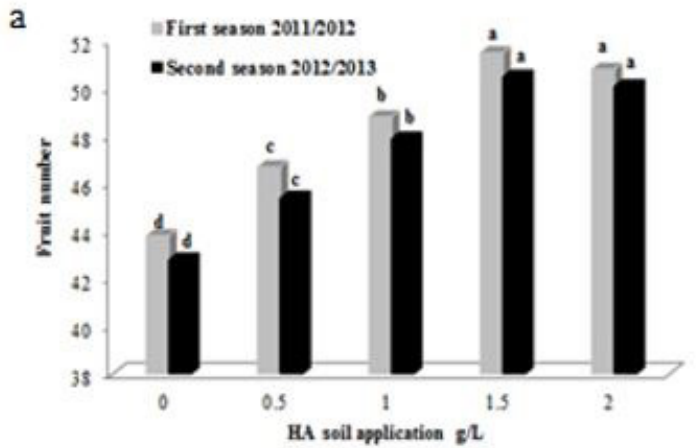

b

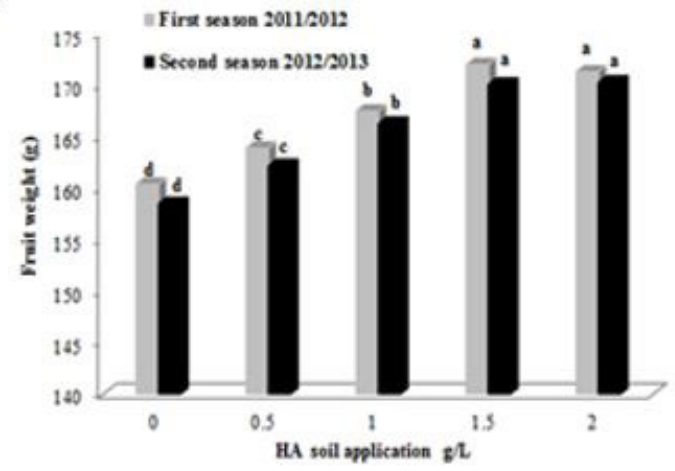

c

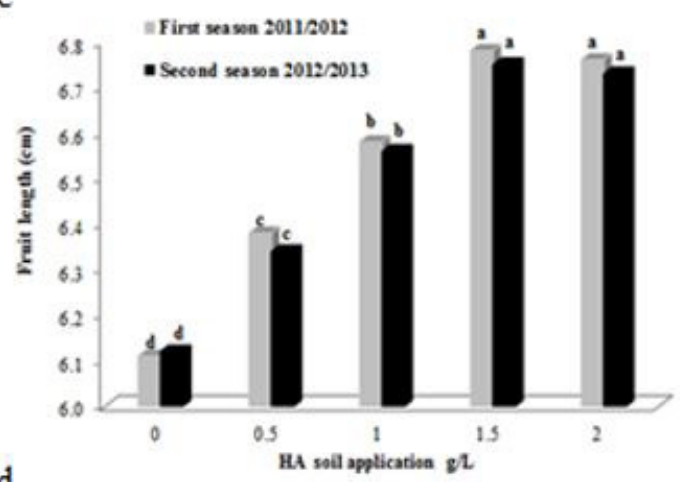

d

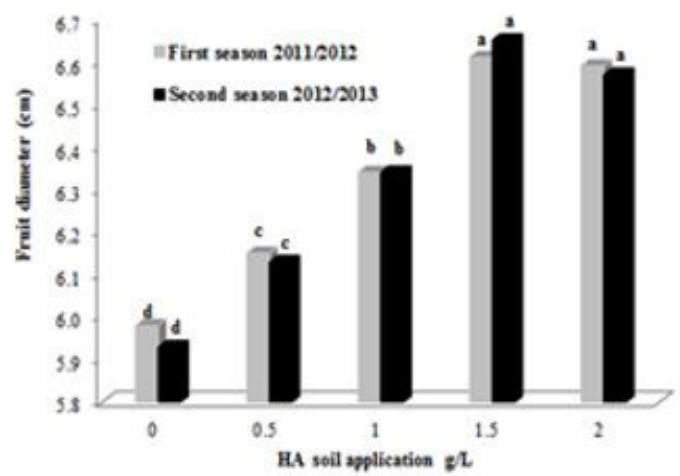

Figure 4. Fruits characteristics of tomato: (A) fruits number plant-1; (B) fruits fresh weight; (C) fruits length; and (D) diameter as affected by the application of humic acid (HA) doses during the 2011-2012 and 2012-2013 seasons. 
to those harvested from plants in control treatment may be attributed to more vigorous growth (Figures 2A-D) of plants, in response to HA application (Aman and Rab, 2013).On one hand, 'Luanova' hybrid was found earlier in fruiting compared to 'Tessera' and 'Savarona' cultivars (Figure 5A ),whereas 'Savarona' produced the lowest yield (both on plant ${ }^{-1}$ and ha ${ }^{-1}$ basis) of tomato fruits (Figures 5B and C) Similar results have been reported by Olaniyi et al. (2010) and Ojo et al. (2013) in Nigeria while they were evaluating different local and exotic varieties of tomato. Hanna (2009) noted in their studies that 'Geronimo' and 'Quest' cultivars of tomato produced significantly heavier fruits compared to 'Trust'. Number of fruits per plant and the average fruits weight harvested from different tomato cultivars largely contribute to significant differences in their yield (Regassa et al., 2012) while 'Luanova' has been characterized as an early maturing cultivar in the vegetable seed catalogue (Keene, 2013).

An increase in dose of HA from 0.5-1.5 $\mathrm{g} \mathrm{L}^{-1}$, caused a significant increase in early yield of tomato fruits but a further increase in dose of HA resulted in decrease of the early yield (Figure 6A). These results are consistent with
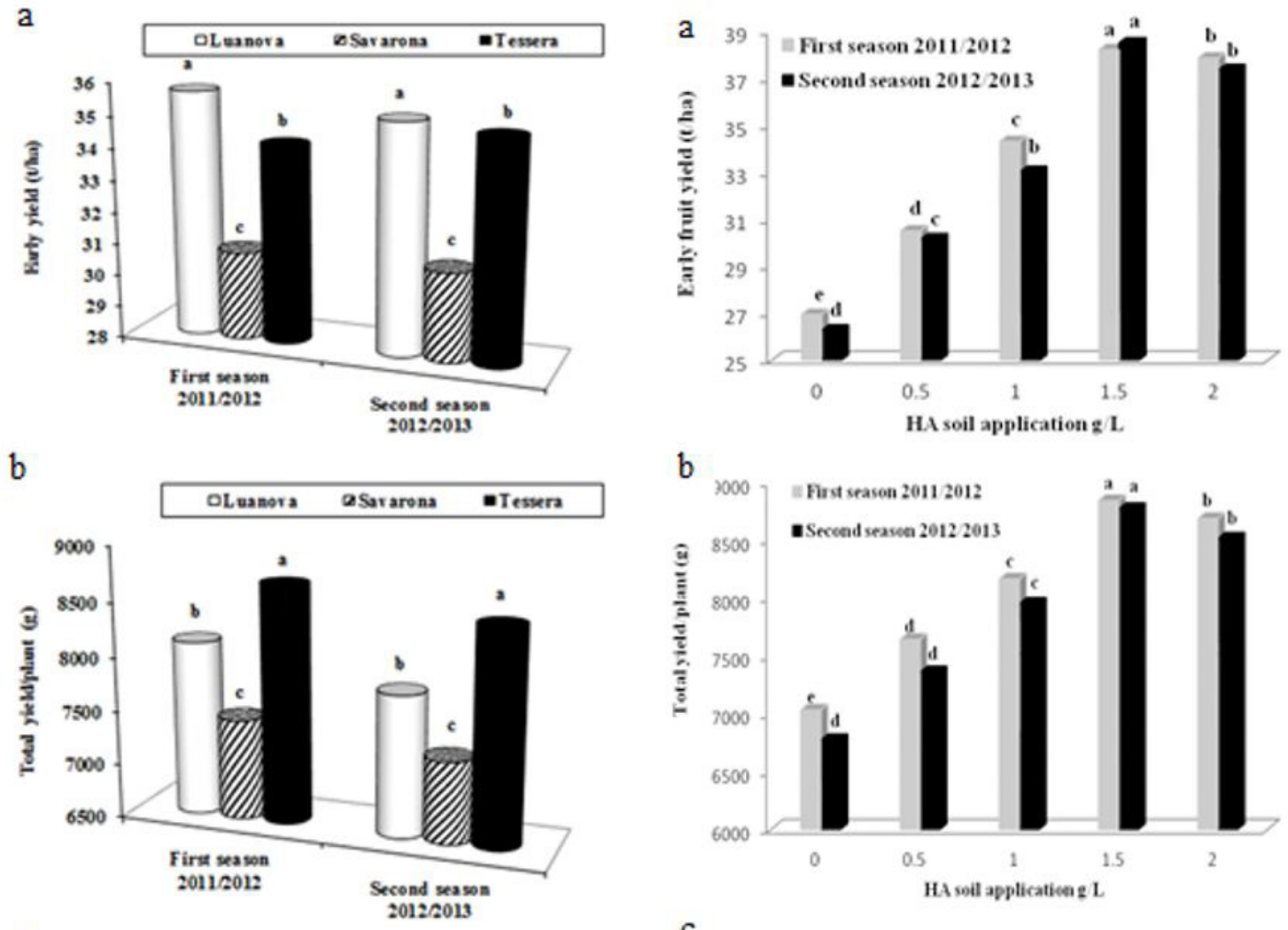

C

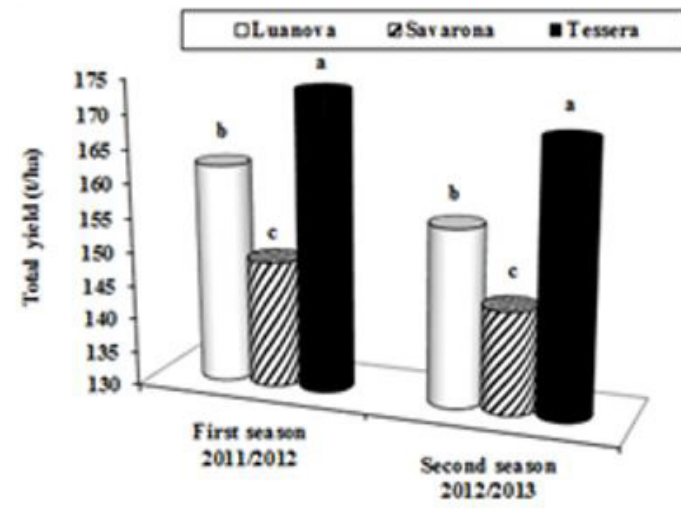

Figure 5. Yield potential of tomato cultivars: (A) early fruits yield; (B) total yield plant-1; and (C) total yield ha-1 during the 20112012 and 2012-2013 seasons.

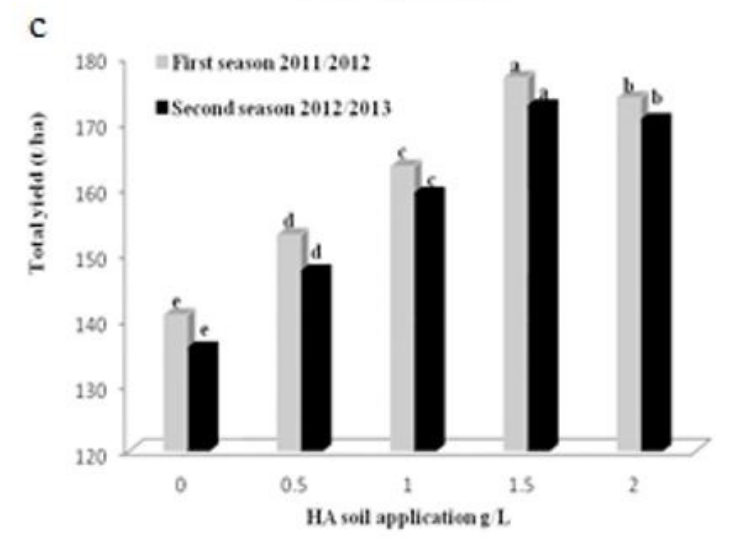

Figure 6. Yield potential of tomato: (A) early fruits yield; (B) total yield plant-1; and (C) total yield ha-1 as affected by the application of humic acid (HA) doses during the 2011-2012 and 2012-2013 seasons. 
those reported by Atiyeh et al. (2002) and Dogan and Demir (2004) in tomato, Ebrahim et al. (2012) in eggplant and by Karakurt et al. (2009) in pepper.

Soil application of HA significantly $(P \leq 0.05)$ increased the yield (6.77-8.84 kg plant ${ }^{-1}$ and $135.485-176.802$ t ha $^{-1}$ ) of tomato fruits in both years, irrespective of the cultivars studied and the dose of HA (Figures $6 \mathrm{~B}$ and $\mathrm{C}$ ). These results are in line with those reported by Asri and Demirtas (2015). However, soil drenching with HA @ $1.5 \mathrm{~g} \mathrm{~L}^{-1}$ resulted in the highest yield of tomato crop both in 2011-12 and 201213 . The increases in yield and yield components may be ascribed to the fact that HA enhances root growth (Khaled and Fawy, 2011) which in turn increases nutrient uptake thereby improving plant growth and yield (Canellas et al., 2008). Ekinci et al. (2015) reported the increase in nutrient uptake by plants to the improved development of their root system. But Mohajerani et al. (2016) suggested that in response to application of HA in three red bean cultivars, the plants exhibit higher leaf area and accumulation of increased levels of photosynthetic material which in turn results in higher grain yields.

Fruits yield is a function of gene expression in the hybrid cultivars in response to the environmental conditions (Salman et al., 2005). Since all tomato cultivars tested during present investigation were grown under the same greenhouse conditions, data on fruits yield and yield components were more or less based their genetic structures.

\subsection{Fruits quality}

The hybrid cultivars tested in present investigation showed variation in quality characters of the fruits. Tomato fruits harvested from plants of 'Tessera' cultivar had higher levels of vitamin C, TA, TSS, and total sugars content followed by those harvested from 'Luanova' and 'Savarona'. However, no significant difference was recorded for dry weight of tomato fruits harvested from plants of 'Tessera' and 'Luanova' cultivars (Table 1). Vitamin C

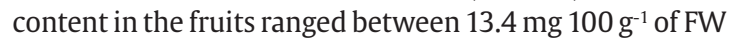

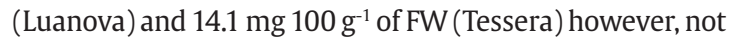
statistically different. Similar results have been reported by Radzevičius et al. (2013). They suggested that environmental conditions and plant cultivar have major influences on vitamin $\mathrm{C}$ content in tomato fruits. Contrarily, the three hybrids tested were significantly different in TSS content of their fruits. Tomato fruits harvested from 'Tessera' cultivar had the highest TTS (4.72\%) followed by those harvested from Luanova (4.2\%) and Savarona (4.07\%). These variations in TSS content in tomato fruits from different cultivars may be attributed to the differences among their fruits dry weight. Being the major constituent of dry matter, TSS increases as the moisture content of fruits decreases (Malundo et al., 1995) thereby affecting the palatability and consumer's acceptability of fruits (Kazemi, 2014).

Total sugars content and acidity are vital traits for tomato taste (Turhan and Seniz, 2009). As revealed in Table 1, total sugars content and TA of the tomato fruits from different cultivars in present studies ranged between 3.08-3.87\% and $0.45-0.52 \%$, respectively. Turhan and Seniz (2009) found that total sugars and TA of ripe tomato fruits from different genotypes were in the range of $1.67-3.73 \%$ and $0.22-0.40 \%$, respectively. Melkamu et al. (2008) reported that total sugars content in 'Marglobe' tomato cultivar were in the range of $0.54-3.44 \%$. Adriana et al. (2006) analyzed TA in several tomato cultivars for processing purposes and recorded the highest TA for 'Perla Clujului' (0.76\%) followed by 'Natalia' ( $0.56 \%)$, whereas TA for 'Indiana', 'Jet', 'Event' and 'Cluj 8-2002' cultivars were in the range of 0.36-0.38\%.

Soil drenching with HA significantly improved fruits dry weight, vitamin C content, TSS, TA and total sugars content in tomato fruits, regardless of cultivar, growing season and the dose of treatment (Table 1). However, application of HA @ $1.5 \mathrm{~g} \mathrm{~L}^{-1}$ outperformed other treatments including control for improvement of most of the quality characters

Table 1. Influence of tomato cultivars and humic acid (HA) application on fruits quality traits during the 2011-2012 and 2012-2013 growing seasons.

\begin{tabular}{|c|c|c|c|c|c|c|c|c|c|c|}
\hline \multirow{2}{*}{ Treatments } & \multicolumn{2}{|c|}{ Dry weight (g) } & \multicolumn{2}{|c|}{$\begin{array}{c}\text { Vit. C (mg } 100 \mathrm{~g}^{-1} \\
\text { FW) }\end{array}$} & \multicolumn{2}{|c|}{ TA (\% citric acid) } & \multicolumn{2}{|c|}{ TSS (degree Brix) } & \multicolumn{2}{|c|}{ Total sugars (\%) } \\
\hline & $\begin{array}{c}2011- \\
2012\end{array}$ & $\begin{array}{c}2012- \\
2013\end{array}$ & $\begin{array}{c}2011- \\
2012\end{array}$ & $\begin{array}{c}2012- \\
2013\end{array}$ & $\begin{array}{l}2011- \\
2012\end{array}$ & $\begin{array}{c}2012- \\
2013\end{array}$ & $\begin{array}{c}2011- \\
2012\end{array}$ & $\begin{array}{l}2012- \\
2013\end{array}$ & $\begin{array}{c}2011- \\
2012\end{array}$ & $\begin{array}{c}2012- \\
2013\end{array}$ \\
\hline \multicolumn{11}{|c|}{ [a] Tomato cultivars } \\
\hline Luanova & $9.74 \mathrm{a}$ & $9.72 \mathrm{a}$ & $13.51 \mathrm{~b}$ & $13.31 \mathrm{c}$ & $0.490 \mathrm{~b}$ & $0.488 \mathrm{~b}$ & $4.22 \mathrm{~b}$ & $4.18 \mathrm{~b}$ & $3.52 \mathrm{~b}$ & $3.60 \mathrm{~b}$ \\
\hline Savarona & $9.43 \mathrm{~b}$ & $9.41 \mathrm{~b}$ & $13.63 \mathrm{~b}$ & $13.74 \mathrm{~b}$ & $0.453 c$ & $0.455 \mathrm{c}$ & $4.09 \mathrm{c}$ & $4.06 \mathrm{c}$ & $3.08 \mathrm{c}$ & $3.31 \mathrm{c}$ \\
\hline Tessera & $9.73 \mathrm{a}$ & $9.70 \mathrm{a}$ & $14.05 \mathrm{a}$ & $14.27 \mathrm{a}$ & $0.514 \mathrm{a}$ & $0.516 \mathrm{a}$ & $4.76 \mathrm{a}$ & $4.69 \mathrm{a}$ & $3.79 \mathrm{a}$ & $3.87 \mathrm{a}$ \\
\hline \multicolumn{11}{|c|}{ [b] HA application $\left(\mathrm{g} \mathrm{L}^{-1}\right)$} \\
\hline 0.0 & 9.39 e & $9.34 \mathrm{~d}$ & $12.60 \mathrm{~d}$ & $12.50 \mathrm{~d}$ & 0.438 e & $0.437 \mathrm{~d}$ & $3.73 \mathrm{~d}$ & $3.67 \mathrm{~d}$ & $3.02 \mathrm{~d}$ & $3.11 \mathrm{~d}$ \\
\hline 0.5 & $9.53 \mathrm{~d}$ & $9.48 \mathrm{c}$ & $13.53 \mathrm{c}$ & $13.33 \mathrm{c}$ & $0.466 \mathrm{~d}$ & $0.466 \mathrm{c}$ & $4.03 \mathrm{c}$ & $3.99 \mathrm{c}$ & $3.34 \mathrm{c}$ & $3.20 \mathrm{c}$ \\
\hline 1.0 & $9.67 \mathrm{c}$ & $9.63 \mathrm{~b}$ & $13.94 \mathrm{~b}$ & $13.81 \mathrm{~b}$ & $0.489 c$ & $0.497 \mathrm{~b}$ & $4.38 \mathrm{~b}$ & $4.34 \mathrm{~b}$ & $3.67 \mathrm{~b}$ & $3.51 \mathrm{~b}$ \\
\hline 1.5 & $9.81 \mathrm{a}$ & $9.76 \mathrm{a}$ & $14.30 \mathrm{a}$ & $14.28 \mathrm{a}$ & $0.514 \mathrm{~b}$ & $0.516 \mathrm{a}$ & $4.79 \mathrm{a}$ & $4.76 \mathrm{a}$ & $3.99 a$ & $3.95 \mathrm{a}$ \\
\hline 2.0 & $9.76 \mathrm{~b}$ & $9.74 \mathrm{a}$ & $14.28 \mathrm{a}$ & $14.42 \mathrm{a}$ & $0.521 \mathrm{a}$ & $0.517 \mathrm{a}$ & $4.83 \mathrm{a}$ & $4.78 \mathrm{a}$ & $4.01 \mathrm{a}$ & $3.98 \mathrm{a}$ \\
\hline
\end{tabular}

Means followed by the same letter in each season are not significantly different at the 0.05 level. 


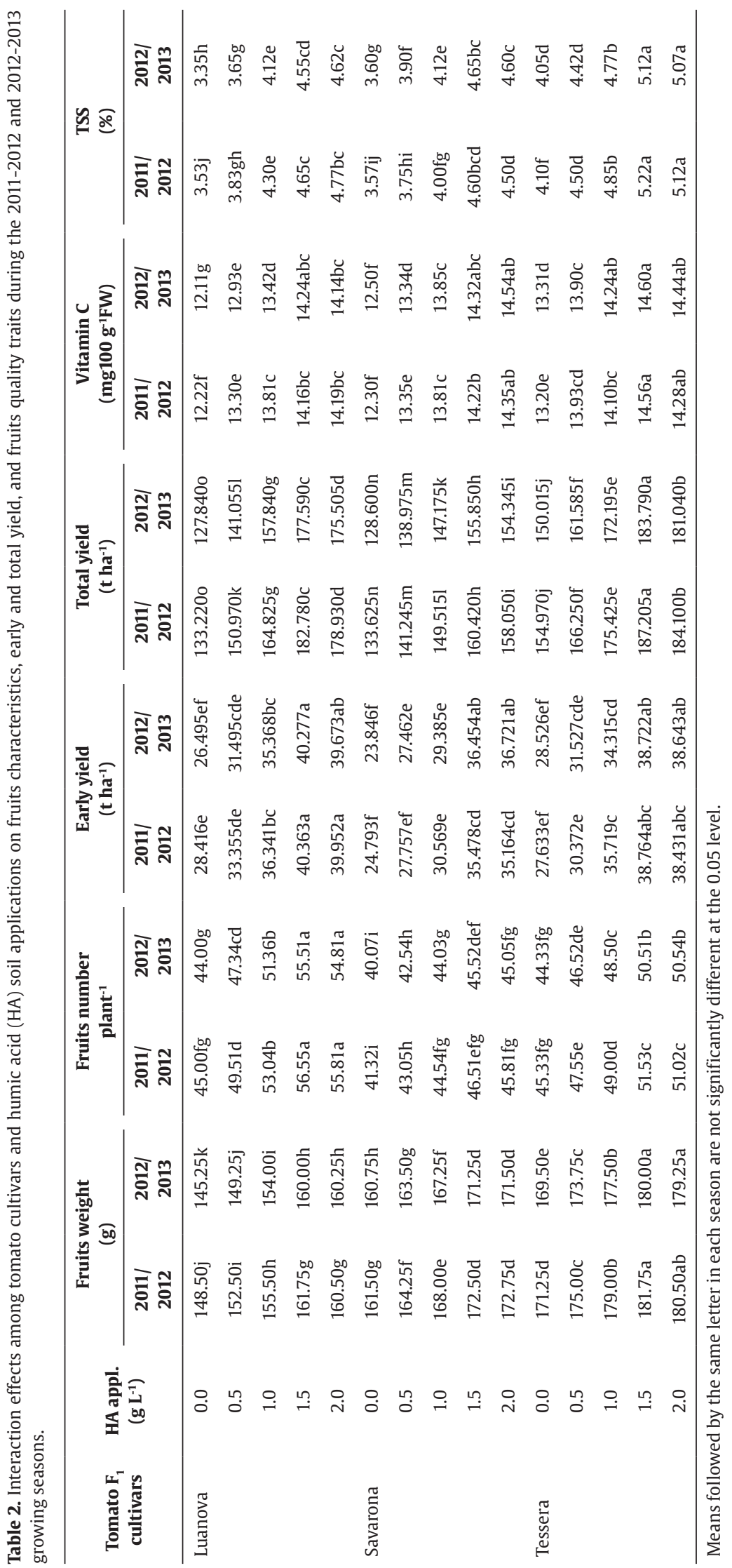


of tomato fruits. These results were in accordance with those reported by Shahmaleki et al. (2014). Padem and Ocal (1999) showed that just a single application of HA during the plant growth cycle was sufficient to increase vitamin $C$ content in tomato fruits grown for processing industry. TA of tomato fruits has been reported to increase with increasing doses of HA application, though remained in the range of $0.3-0.5 \%$ citric acid (Lima et al., 2011; George et al., 2004; Asri and Demirtas, 2015). Similarly, TSS and dry matter content of tomato fruits have been reported to increase by the application of HA @ 10-20 mL $\mathrm{L}^{-1}$ (Yildirim, 2007).

These results suggest that application of HA may exhibit stimulatory effects on tomato plants thereby improving their efficiency to uptake major nutrients, especially P and $\mathrm{K}$ from the soil that in turn improves the quality of tomato fruits. Mikkelsen (2005) reported that soil application of potassium nitrate @ $200 \mathrm{~kg} \mathrm{ha}^{-1}$ improved the transport of photosynthates (i.e., starch, sugar, organic acids etc.) which in turn increased the source-sink ratio in plants. Wang et al. (2009) showed that soil application of K fertilizer improves TA of cherry tomato fruits. Asri and Demirtas (2015) suggested that soil application of large quantities of $\mathrm{K}$ fertilizers compels plants to produce proportional amounts of organic acids in order to neutralize absorbed $\mathrm{K}$ ions.

\subsection{Cultivar $x$ HA Interaction}

Effects of cultivar-by-application of HA interaction on productivity and quality of tomato fruits are illustrated in Table 2. The results from present investigation revealed relationships between tomato hybrid cultivars and application of HA while the interaction of these two variables affect the yield and yield components of tomato crop. Significant differences were recorded for productivity and quality of tomato fruits among the hybrid cultivars tested in combination with the application of HA. Interactions between 'Terresa' cultivar and application of HA @ $1.5 \mathrm{~g} \mathrm{~L}^{-1}$ was the strongest ones for total yield and fresh fruits weight. The 'Luanova' and 'Tessera' cultivars were, however, not significantly different for their early yields when supplied with the same rates (1.5-2.0 $\left.\mathrm{g} \mathrm{L}^{-1}\right)$ of HA by soil drenching. Dinu et al. (2015) reported similar results in three tomato cultivars tested in their studies in response to the application of HA. In present investigation, the varietal difference of response to soil application of HA may be attributed to the differences in genetic structure/makeup of individual tomato cultivars used (Salman et al., 2005).

Soil application of HA also showed positive effects on the quality (vitamin ' $C$ ' and TSS) of tomato fruits harvested from the three tomato cultivars investigated (Table 2). The highest vitamin ' $C$ ' and TSS content were recorded for the fruits harvested from the plants of 'Tessera' cultivar that was supplied with $1.5 \mathrm{~g} \mathrm{~L}^{-1}$ of HA whereas tomato fruits harvested from plants of 'Luanova' cultivar in the control treatment had the lowest values for both vitamin ' $C$ ' and TSS content. Recently, Shahmaleki et al. (2014) demonstrated that foliar application of HA improved fresh firmness, antioxidant activity, vitamin ' $C$ ', total phenolic, and TSS content in tomato fruits of 'Izabella' cultivar.

\section{Conclusions}

Present studies reveal that among the three tomato hybrid cultivars tested, 'Tessera' cultivar performed better than others in terms of productivity and quality of fruits though 'Luanova' cultivar yielded earlier fruits and exhibited higher number of tomato fruits per plant. Soil drenching of HA @ $1.5 \mathrm{~g} \mathrm{~L}^{-1}$ increases the efficiency of 'Tessera' cultivar to produce higher yield of quality fruits under protected environment.

\section{Acknowledgements}

Thanks to the Deanship of Scientific Research, King Saud University and Agricultural Research Center, College of Food and Agriculture Sciences, for the financial support.

\section{References}

ABDEL-MAWGOUD, A.M.R., EL-GREADLY, N.H., HELMY, Y.I. and SINGER, S.M., 2007. Responses of tomato plants to different rates of humic-based fertilizer and NPK fertilization. Journal of Applied Sciences Research, vol. 3, no. 2, pp. 169-174.

ADRIANA, S., JIDAVU, M., SESTRAS, R., APAHIDEAN, M., HĂRSAN, E., TĂMAS, E. and GAO, Y., 2006. The response of several tomato cultivars for processing in central Transylvania conditions. II. Fruitss quality. Notulae Botanicae Horti Agrobotanici Cluj-Napoca, vol. 34, no. 1, pp. 62-68. http://dx.doi.org/10.15835/nbha341276.

AGYEMAN, K., OSEI-BONSU, I., BERCHIE, J., OSEI, M., MOCHIAH, M., LAMPTEY, J., OSEI, K. and BOLFREY-ARKU, G., 2014. Effect of poultry manure and different combinations of inorganic fertilizers on growth and yield of four tomato varieties in Ghana. Agricultural Science, vol. 2, no. 4, pp. 27-34. http:// dx.doi.org/10.12735/as.v2i4p27.

AL-ROHILY, K.M., GHONEIM, A.M., MODAIHSH, A.S. and MAHJOUB, M.O., 2013. Phosphorus availability in calcareous soil amend with chemical phosphorus fertilizer, cattle manure compost and sludge manure. International Journal of Soil Science, vol. 8, no. 1, pp. 17-24. http://dx.doi.org/10.3923/ijss.2013.17.24.

AMAN, S. and RAB, A., 2013. Response of tomato to nitrogen levels with or without humic acid. Sarhad Journal of Agriculture, vol. 29, no. 2, pp. 181-186.

ASRI, F.O. and DEMIRTAS, E., 2015 [viewed 26 June 2016]. Changes in fruits yield, quality and nutrient concentrations in response to soil humic acid applications in processing tomato. Bulgarian Journal of Agricultural Science [online], vol. 21, no. 3, pp. 585591. Available from: https://www.agrojournal.org/21/03-17.pdf

ASSOCIATION OFFICIAL ANALYTICAL CHEMISTRY - AOAC 2005. Official method of analysis. 18th ed. Washington.

ATIYEH, R.M., LEE, S., EDWARDS, C.A., ARANCON, N.Q. and METZGER, J.D., 2002. The influence of humic acids derived from earthworm-processed organic wastes on plant growth. Bioresource Technology, vol. 84, no. 1, pp. 7-14. http://dx.doi. org/10.1016/S0960-8524(02)00017-2. PMid:12137272.

CANELLAS, L.P., TEIXEIRA-JUNIOR, L.R., DOBBSS, L.B., SILVA, C.A., MEDICI, L.O., ZANDONADI, D.B. and FACANHA, A.R., 2008. Humic acids cross interactions with root and organic acids. Annals of Applied Biology, vol. 153, no. 1, pp. 157-166. http:// dx.doi.org/10.1111/j.1744-7348.2008.00249.x.

DINU, M., DUMITRU, M.G. and SOARES, R., 2014. The effect of antioxidant substances and humic acid on the seeds germination 
of some vegetable species. Annals of the University of Craiova, vol. 19, no. 4, pp. 155-160.

DINU, M., DUMITRU, M.G. and SOARES, R., 2015 [viewed 26 June 2016]. The effect of some bio-fertilizers on the biochemical components of the tomato plants and fruitss. Bulgarian Journal of Agricultural Science [online], vol. 21, no. 5, pp. 998-1004. Available from: https://www.agrojournal.org/21/05-12.pdf

DIREKVANDI, S.N., ANSARI, N.A. and DEHCORDIE, F.S., 2008. Effect of different levels of nitrogen fertilizer with two types of bio-fertilizers on growth and yield of two cultivars of tomato (Lycopersicon esculentum Mill). Asian Journal of Plant Sciences, vol. 7, no. 8, pp. 757-761. http://dx.doi.org/10.3923/ ajps.2008.757.761.

DOGAN, E. and DEMIR, K., 2004. Determination of yield and fruits characteristics of tomato crop grown in humic acids-added aggregate culture in greenhouse conditions. In: VI National Vegetable Symposium, 21-24 September 2004, Canakkale, Turkey. Turkey, pp. 218-224.

DURSUN, A., GUVENC, I. and TURAN, M., 2013. Effects of different levels of humic acid on seedling growth and macro and micronutrient contents of tomato and eggplant. Acta Agrobotanica, vol.55, no. 2, pp. 81-88. http://dx.doi.org/10.5586/ aa.2002.046.

EBRAHIM, A., MOHAMMAD, K.M., MARAL, M., HAMID, R. and BOZORGI, A., 2012. Effects of bio, mineral nitrogen fertilizer management, under humic acid foliar spraying on fruits yield and several traits of eggplant (Solanum melongena L.). African Journal of Agricultural Research, vol. 7, no. 7, pp. 1104-1109. http://dx.doi.org/10.5897/AJAR11.1833.

EKINCI, M., ESRINGÜ, A., DURSUN, A., YILDIRIM, E., TURAN, M., KARAMAN, M.R. and ARJUMEND, T., 2015. Growth, yield, and calcium and boron uptake of tomato (Lycopersicon esculentum L.) and cucumber (Cucumis sativus L.) as affected by calcium and boron humate application in greenhouse conditions. Turkish Journal of Agriculture and Forestry, vol. 39, pp. 613-632. http:// dx.doi.org/10.3906/tar-1406-59.

FELEAFEL, M.N. and MIRDAD, Z.M., 2014 [viewed 26 June 2016]. Ameliorating tomato productivity and water-use efficiency under water salinity. Journal of Animal and Plant Sciences [online], vol. 24, no. 1, pp. 302-309. Available from: http:// www.thejaps.org.pk/docs/v-24-1/42.pdf

FOOD AND AGRICULTURE ORGANIZATION OF THE UNITED NATIONS - FAO, 2016 [viewed 26 June 2016]. FAOSTAT [online]. Rome: Crop Production, Statistics Division. Available from: http:// www.faostat.fao.org

GEORGE, B., KAUR, C., KHURDIYA, D.S. and KAPOOR, H.C., 2004. Antioxidants in tomato (Lycopersium esculentum) as a function of genotype. Food Chemistry, vol. 84, no. 1, pp. 45-51. http:// dx.doi.org/10.1016/S0308-8146(03)00165-1.

GOULD, A.A., 1983. Tomato production and quality evaluation. New York: AVI Publishing, $478 \mathrm{p}$.

HANNA, H.Y., 2009. Influence of cultivar, growing media, and cluster pruning on greenhouse tomato yield and fruits quality. HortTechnology, vol. 19, no. 2, pp. 395-399. http://dx.doi. org/10.21273/HORTSCI.19.2.395.

KARAKURT, Y., UNLU, H., UNLU, H. and PADEM, H., 2009. The influence of foliar and soil fertilization of humic acid on yield and quality of pepper. Acta Agriculturæ Scandinavica. Section B, Soil and Plant Science, vol. 59, no. 3, pp. 233-237. http://dx.doi. org/10.1080/09064710802022952.

KAZEMI, M., 2013. Vegetative and reproductive growth of tomato plants affected by calcium and humic acid. Bulletin of Environment, Pharmacology and Life Sciences, vol. 2, no. 11, pp. 24-29.

KAZEMI, M., 2014. Effect of foliar application of humic acid and calcium chloride on tomato growth. Bulletin of Environment. Pharmacology and Life Sciences, vol. 3, no. 3, pp. 41-46.

KEENE, R.M., 2013. Vegetable seed catalogue. The Netherland: EnzaZaden Export B. V. Enkhuizen, pp. 32-33.

KHALED, H. and FAWY, H., 2011. Effect of different levels of humic acids on the nutrient content, plant growth and soil properties under conditions of salinity. Soil and Water Research, vol. 6, no. 1, pp. 21-29. http://dx.doi.org/10.17221/4/2010-SWR.

LIMA, A.A., ALVARENGA, M.A., RODRIGUES, L. and CHITARRA, A.B., 2011. Yield and quality of tomato produced on substrates and with application of humic acids. Horticultura Brasileira, vol. 29, no. 3, pp. 269-274. http://dx.doi.org/10.1590/S010205362011000300002.

LIU, C. and COOPER, R.J., 2002. Humic acid application does not improve salt tolerance of hydroponically grown creeping bent grass. Journal of the American Society for Horticultural Science, vol. 127, no. 2, pp. 219-223. http://dx.doi.org/10.21273/ JASHS.127.2.219.

LOTFI, R., GHARAVI-KOUCHEBAGH, P. and KHOSHVAGHTI, H., 2015. Biochemical and physiological responses of Brassica napus plants to humic acid under water stress. Russian Journal of Plant Physiology: a Comprehensive Russian Journal on Modern Phytophysiology, vol. 62, no. 4, pp. 480-486. http://dx.doi. org/10.1134/S1021443715040123.

MAHMOUDI, M., SAMAVAT, S., MOSTAFAVI, M., KHALIGHI, A. and CHERATI, A., 2013. The effects of proline and humic acid on quantitative properties of kiwifruits. International Research Journal of Applied and Basic Sciences, vol. 6, no. 8, pp. 1117-1119.

MALUNDO, M., SHEWFELT, R. and SCOTT, J., 1995. Flavor quality of fresh tomato (Lycopersicon esculentum Mill.) as affected by sugar and acid levels. Postharvest Biology and Technology, vol. 6, no. 1-2, pp. 103-110. http://dx.doi.org/10.1016/09255214(94)00052-T.

MELKAMU, M., SEYOUM, T. and WOLDETSADIK, K., 2008. Effects of pre-and post-harvest treatments on changes in sugar content of tomato. African Journal of Biotechnology, vol. 7, no. 8, pp. 1139-1144.

MIKKELSEN, R.L., 2005. Humic materials for agriculture. Better Crops with Plant Food, vol. 89, no. 3, pp. 7-10.

MOHAJERANI, S., FAZEL, M.H., MADANI, H., LAK, S. and MODHEJ, A., 2016. Effect of the foliar application of humic acid on red bean cultivars (Phaseolus vulgaris L.). Journal of Experimental Biology and Agricultural Sciences, vol. 4, no. 5, pp. 519-524. http://dx.doi.org/10.18006/2016.4(5).519.524.

MOTAGHI, S., 2014. The effect of different levels of humic acid and potassium fertilizer on physiological indices of growth. International Journal of Biosciences, vol. 5, no. 2, pp. 99-105. http://dx.doi.org/10.12692/ijb/5.2.99-105.

NOUR, V., TRANDAFIR, I. and IONICA, M.E., 2013. Antioxidant compounds, mineral content and antioxidant activity of several tomato cultivars grown in Southwestern Romania. Notulae Botanicae Horti Agrobotanici Cluj-Napoca, vol. 41, no. 1, pp. 136-142. http://dx.doi.org/10.15835/nbha4119026.

OJO, G.O., EKOJA, E.E. and UKPOJU, O.P., 2013. Evaluation of tomato (Lycopersicon lycopersicum Mill.) for fruits yield and yield components in the southern Guinea Savanna ecology of Nigeria. International Journal of Agronomy and Agricultural Research, vol. 3, no. 3, pp. 1-5. 
OLANIYI, J.O., AKANBI, W.B., ADEJUMO, T.A. and AKANDE, O.G., 2010. Growth, fruits yield and nutritional quality of tomato varieties. African Journal of Food Science, vol. 4, no. 6, pp. 398-402.

PADEM, H. and OCAL, A., 1999. Effects of humic acid applications on yield and some characteristics of processing tomato. Acto Horticulturae, no. 487, pp. 159-164. http://dx.doi.org/10.17660/ ActaHortic.1999.487.20.

RADZEVIČIUS, A., VIŠKELIS, P., VIŠKELIS, J., BOBINAITĖ, R., KARKLELIENĖ, R. and JUŠKEVIČIENĖ, D., 2013. Tomato fruits quality of different cultivars growth in Lithuania. International Journal of Agricultural and Biosystems Engineering, vol. 7, no. 7, pp. 381-384. http://dx.doi.org/10.5281/zenodo.1087446.

REGASSA, M.D., MOHAMMED, A. and BANTTE, K., 2012. Evaluation of tomato (Lycopersicon esculentum Mill) genotypes for yield and yield component. The African Journal of Plant Science and Biotechnology, vol. 6, no. 1, pp. 45-49.

RICHARDSON, K.V.A., 2012. The effects of pruning versus nonpruning on quality and yield of staked fresh-market tomatoes. Gladstone Road Agricultural Centre Crop Research Report No. vol. 10, pp. 1-10.

SAJID, M., RAB, A., SHAH, S.T., JAN, I., HAQ I., HALEEMA, B., ZAMIN, M., ALAM, R. and ZADA, H., 2012. Humic acids affect the bulb production of onion cultivars. African Journal of Microbiological Research, vol. 6, no. 28, pp. 5769-5776.

SALMAN, S.R., ABOU-HUSSEIN, S.D., ABDEL-MAWGOUD, A.M. and EL-NEMR, M.A., 2005. Fruits yield and quality of watermelon as affected by hybrids and humic acid application. Journal of Applied Sciences Research, vol. 1, no. 1, pp. 51-58.

SHAHMALEKI, S.K., PEYVAST, G.A. and GHASEMNEZHAD, M., 2014. Acid humic foliar application affects fruits quality characteristics of tomato (Lycopersicon esculentum cv. Izabella). Agriculture Science and Development, vol. 3, no. 10, pp. 312-316.
SHEHATA, S.A., GHARIB, A.A., MOHAMED, M., ABDEL, M.K., GAWAD, F. and EMAD, A.S.H., 2011 [viewed 26 June 2016]. Influence of compost, amino acids and humic acids on the growth, yield and chemical parameters of strawberries. Journal of Medicinal Plants Research [online], vol. 5, no. 11, pp. 2304-2308. Available from: http://www.academicjournals.org/JMPR

SNYDER, R.G., 2001. Greenhouse tomato handbook. Mississippi: Mississippi State University Extension Service. Publ., no. 1828.

STATISTICAL ANALYSIS SYSTEM - SAS, 2008. SAS statistical software version 8.1. Cary: SAS Institute.

STEEL, R.G.D. and TORRIE, J.H., 1980. Principles and procedures of statistics: a biometrical approach. 2nd ed. New York: McGraw Hill.

TABASI, A., NEMATI, H. and AKBARI, M., 2013. The effects of planting distances and different stages of maturity on the quality of three cultivars of tomatoes (Lycopersicon esculentum Mill). Notulae Scientia Biologicae, vol. 5, no. 3, pp. 371-375. http:// dx.doi.org/10.15835/nsb539091.

TURHAN, A. and SENIZ, V., 2009 [viewed 26 June 2016]. Estimation of certain chemical constituents of fruitss of selected tomato genotypes grown in Turkey. African Journal of Agricultural Research [online], vol. 4, no. 10, pp. 1086-1092. Available from: http://www.academicjournals.org/AJAR

WANG, Y., LIU, R., HUANG, S. and JIN, J., 2009. Effects of potassium application on flavor compounds of cherry tomato fruitss. Journal of Plant Nutrition, vol. 32, no. 9, pp. 1451-1468. http:// dx.doi.org/10.1080/01904160903092663.

YILDIRIM, E., 2007. Foliar and soil fertilization of humic acid affect productivity and quality of tomato. Acta Agriculturæ Scandinavica. Section B, Soil and Plant Science, vol. 57, no. 2, pp. 182-186. http://dx.doi.org/10.1080/09064710600813107. 